\title{
DES-AUTORIZADOS: NARRAR AL PAÍS EN CLAVE EN TIEMPOS DE LA REVOLUCIÓN BOLIVARIANA
}

\author{
POR \\ Víctor CARREÑo \\ Universidad de Zulia, Venezuela
}

Después de Huelepega, ley de la calle (1999) y Punto y raya (2004), películas con las que Elia Schneider obtuvo una muy buena acogida en el público, la directora realiza Des-autorizados (2010), que no sigue el realismo social. Esta obra mezcla tendencias estéticas (camp, surrealismo, teatro del absurdo) y géneros (comedia, drama, melodrama, cartoon). Su hibridez estética proviene de la narrativa del cine de arte y ensayo. Dentro de su heterogeneidad, ésta se distancia de la narrativa y el teatro realistas del siglo XIX y retoma propuestas vanguardistas que cuestionan la realidad y sus representaciones. Genera así un arte que atenúa las relaciones entre causa y efecto, con personajes que se van construyendo a la deriva o que no encuentran una resolución en su trama, un cine que mezcla de un modo muy particular realismo "objetivo", realismo "expresivo" o subjetivo y comentario narrativo (Bordwell 205-207). Des-autorizados alude a la lucha entre autor y personaje, con referencias a Pirandello, Fellini y Chejov, y que remite a la búsqueda de la autonomía del arte, más allá de cualquier intromisión externa. Por esta ventana Schneider nos asoma a referentes políticos y estéticos latinoamericanos. Sin prescindir de unas claves enraizadas en las vanguardias, antes bien revisitándolas con irreverencia, Des-autorizados nos ofrece una lectura alegórica, en clave política, de Venezuela en los tiempos de la llamada Revolución Bolivariana. Es un cine experimental, situado más allá de las expectativas comerciales de Hollywood, que sin embargo se proyecta también como una reflexión personal y nacional. ${ }^{1}$

La narrativa de Des-autorizados se desarrolla en tres planos. Elia K (quien es Schneider, como cineasta fabuladora) imagina la vida de Elías Martínez, un escritor aparentemente convencional (bohemio, pobre y "cliché"). De la noche a la mañana, éste

\footnotetext{
Según Schneider, Des-autorizados: "Hizo 14 o 16 mil espectadores, mientras que Huelepega y Punto y raya rebasaron los 250.000" (Entrevista personal 4 diciembre 2013). Selección Oficial nominada a los premios Golden Globet. 13 Festival Internacional de Cine de Shanghai (junio 2010). Categoría A. Actualmente Schneider trabaja en el rodaje del largometraje Tamara, basado en la vida de Tamara Adrián, activista en defensa de los derechos de la comunidad LGBT en Venezuela. Agradezco a la directora por autorizar la reproducción de imágenes de Des-autorizados para este artículo.
} 
se encuentra en líos cuando su productor, Oscar, decide vender, sin él saberlo, su guión teatral Amantes sin destino, lo que obliga a Elías a someterse a los dictados del nuevo dueño de la obra, el importador de prótesis Bruno Da Mata, mientras sus personajes se rebelan, "des-autorizados", contra la decisión de su autor. A través de Elías, escritor del guión teatral cuya versión originalél modificará, adaptándose a las necesidades de quienes ahora tienen control sobre él, se sugiere la problemática entre Estado, sociedad y libertad creativa del artista, y que en el contexto en que se produce la película remite en última instancia a las situaciones incómodas en la relación entre cine y Estado en Venezuela en lo que va del siglo XXI. El objetivo de este artículo es describir la construcción de una alegoría política en Des-autorizados, en respuesta a estas circunstancias. Revisaré primero las políticas culturales de la Revolución Bolivariana y su incidencia en el cine nacional. Luego a través de una reflexión teórica sobre la alegoría abordaré en Des-autorizados, desde su estética no realista e irónica, la representación de un nuevo espacio social, pero también la resemantización de la historia y las identidades en el contexto de la Revolución Bolivariana.

\section{Políticas culturales en la Revolución Bolivariana}

La relación entre cine y Estado ha sido fundamental para el desarrollo de la actividad cinematográfica desde principios del siglo XX en Venezuela, cambiando según las épocas. El siglo XXI no ha sido una excepción, pero para comprender esta relación debemos formarnos una idea de las políticas culturales durante la Revolución Bolivariana, ya que éstas inciden sobre el cine, y a su vez necesitan ser inscritas en la historia política nacional.

La historia de Venezuela en el siglo XXI ha estado marcada por profundas y violentas contradicciones. Dentro de una "lucha hegemónica" por el poder, ha tenido un fuerte protagonismo la lucha entre medios privados y el Estado, resuelta a la larga a favor de éste, dejando no pocas veces al ciudadano de a pie vacilante ante lo que Margarita López Maya llama "la deriva autoritaria de Venezuela" y cuyo desenlace más trágico ocurrió el 11 de abril de 2002, día que condujo a un fallido golpe de Estado liderado por sectores de la oposición enfrentados al gobierno, precedido por el antagonismo de "dos polos políticos que 'imbuidos de indignación moral' se sentían con legítimo derecho a jugar por fuera del estado de derecho" ("El 11A y la deriva autoritaria" 14). ${ }^{2}$

2 Este estado de derecho tambaleante ha marcado la institucionalidad en estos años. Así como sectores de la oposición resemantizaron el golpe de Estado contra Chávez como un acto justificable frente a un "vacío de poder", el oficialismo se ha referido al golpe de Estado de Chávez en 1992 contra un presidente elegido democráticamente como una "rebelión cívico militar". Una crisis reciente fue la del 10 de enero de 2013, cuando Chávez no tomó posesión de la presidencia, como lo pedía la Constitución, por estar enfermo de cáncer. Al final se realizó la "juramentación” del "pueblo" en lugar de Chávez. 
De esta crisis de poder surgirá paulatinamente la construcción de una nueva hegemonía comunicacional por el Estado que va de la mano de la busca de una nueva hegemonía cultural, expresada en las políticas culturales. ${ }^{3}$

Durante el sistema democrático surgido del Pacto de Punto Fijo (1958-1998), se presentaron también contradicciones que de algún modo prefiguran esta coyuntura. En medio de las libertades políticas, se conocieron casos de censuras tanto de parte del Estado como de los medios privados, para proteger sus intereses políticos y económicos de críticas u opiniones desfavorables (Bermúdez, "Libertad de expresión y hegemonía en Venezuela" 45). La falta de una política comunicacional, así como la crisis del Estado y los partidos tradicionales en los últimos tiempos del Pacto de Punto Fijo, permitió a los medios de comunicación convertirse en actores políticos; este desequilibrio explica las tensiones entre los medios privados y el Estado al principio de la Revolución Bolivariana, inclinándose esta lucha a favor de un Estado que le disputa la hegemonía comunicacional e ideológica a los medios privados a partir de 2002 (Bermúdez, "Libertad de expresión" 46). El paso de estos últimos diez años, del 2003 al 2013, reforzó esa tendencia. Para mostrar los ejemplos más relevantes, es útil acudir al resumen de ese periodo realizado por Carolina Acosta-Alzuru. En el 2003, la telenovela Cosita rica, ganadora del rating por el canal privado Venevisión, "incluía personajes alegóricos a personalidades políticas [...] Olegario Pérez era una metáfora de tinte opositor del entonces presidente, Hugo Chávez". Como la telenovela hacía referencia al proceso de referéndum revocatorio contra el presidente, esto produjo ciertos roces con el gobierno, y en la segunda mitad del 2004, el canal ya no tenía una orientación opositora; Televen redujo sus espacios de oposición y a RCTV le fue negada la renovación de su licencia, siendo sustituida por la estatal TVES. Concluye Acosta-Alzuru: "Una mezcla de leyes de contenido, la autocensura como mecanismo de supervivencia y compras de medios por grupos cercanos al gobierno han reducido de manera significativa el espacio para las voces disidentes". ${ }^{4}$ La autocensura, admite Acosta-Alzuru, es difícil de documentar y no siempre se puede probar. Investigadora desde hace años de la trayectoria de Leonardo Padrón, confirma su autocensura como guionista de Cosita rica, como ha sucedido con otros medios. El caso es pertinente pues entre las opiniones del público venezolano el año de estreno de Des-autorizados hay quienes han afirmado que uno de los temas de

\footnotetext{
3 La presencia dominante de los medios privados como actores políticos cambiará más tarde, teniendo mayor protagonismo los partidos de oposición. La polarización, sin embargo, ha continuado. En las elecciones presidenciales del 2013 el país quedó dividido en dos mitades muy similares (50, 61 \% votos para el oficialismo, 49,12\% votos para la oposición, según web del CNE).

4 Ha habido agresiones a medios y periodistas no oficialistas, denunciadas por organismos de derechos humanos; estas agresiones también se han dado por parte de opositores a periodistas de canales del Estado, pero en el primer caso ha sido acompañada por la indiferencia del Estado y algunas veces por la movilización de grupos "estilo milicias" (Bermúdez 52-3).
}

Revista Iberoamericana, Vol. LXXXI, Núm. 251, Abril-Junio 2015, 601-625 ISSN 0034-9631 (Impreso)

ISSN 2154-4794 (Electrónico) 
la película es la autocensura. ${ }^{5}$ Pero el control de contenidos también ha afectado a los medios estatales, aunque estos casos trascienden menos. Mencionaré sólo el del Noticiero indígena, programa de televisión de la estatal Vive TV, realizado por Yanilú Ojeda y Leiqui Uriana (indígena wayuu), el cual después de denunciar distintas situaciones de violación de los Derechos Humanos en el estado Zulia, dejó de ser transmitido ("Carta a Blanca Ekhout Presidenta de Vive TV"). Posteriormente volvió a salir al aire, pero para entonces la documentalista Yanilú Ojeda había sido despedida del canal, motivando una carta de protesta por miembros de la etnia wayuu, en solidaridad por la denuncia del Noticiero indígena de la situación precaria de los niños wayuu que trabajan en un Relleno sanitario ("Carta Abierta a Blanca Eckhout Presidenta Vive TV"). Este hecho es pertinente pues muestra una continuidad entre lo acontecido con Huelepega, ley de la calle y el Noticiero indígena. En ambos casos se denunció la miseria de los niños y en ambos, antes de y durante la Revolución Bolivariana, actuó la censura.

Esta restricción de los contenidos críticos es paralela a una saturación de la presencia del presidente en los medios, sobre todo a través de numerosas cadenas radio-televisivas, como se ha documentado con cifras (Bermúdez, "Libertad de expresión" 54-55). Esta presencia ha servido en varias ocasiones para descalificar a opositores como "escuálidos" o "vendepatrias", que trasciende lo anecdótico, pues se institucionaliza su exclusión de puestos de trabajos en organismos oficiales a través de la llamada Lista Tascón. ${ }^{6}$ Esta contiene la identificación de las personas que firmaron solicitando un referéndum para la revocación del mandato de Chávez. ${ }^{7}$

Así como en el plano comunicacional, se planteó también la construcción de una nueva hegemonía cultural, con la cual se proponía erradicar el "elitismo" y "personalismo" del pasado con una nueva institucionalidad cultural, creada a partir de instituciones heredadas. Sin embargo, no fue un "sistema descentralizado fuerte" lo que sucedió (Muñoz). El CONAC dejó de ser el organismo encargado de diseñar

5 En el blog Panfletonegro.com con fecha del 4 de abril de 2010, afirma el bloguero "Modo": "el tema de la película es la autocensura de los realizadores". Y "Sergio M." dice para la misma fecha que el tema es la "autocensura". Estos comentarios son, sin embargo, para hacer descalificaciones personales, caso no aislado entre los blogs venezolanos de crítica literaria y cultural. Ver de Antonieta Alario "El anonimato en la crítica literaria o cómo destruir al enemigo sin correr ningún riesgo".

6 Los descalificativos son usados frecuentemente por chavistas y opositores, llamando estos a los primeros "hordas" y "turbas" (López Maya, "El 11A y la deriva autoritaria" 18). Estas discriminaciones son repudiables, pero en el caso del chavismo tienen además un correlato institucional en prácticas oficiales y excluyentes como la de la Lista Tascón. Luego de la muerte de Chávez a principios del 2013 esta exclusión ha proseguido.

7 En una intervención por televisión del 15 de abril de 2005, Chávez dijo: "Entiérrese la Lista de Luis Tascón. Seguramente cumplió un papel importante en un momento determinado, pero no, no, ya eso pasó". Esta declaración confirma que la discriminación política era oficialmente conocida. Varias denuncias posteriores han afirmado que la Lista siguió usándose. Ver documental La lista. Un pueblo bajo sospecha (2005). 
y ejecutar las políticas culturales, sus direcciones cambiaron de nombre y pasaron a ser Plataformas (Bermúdez y Sánchez 561-562). La Plataforma del Cine y los Medios audiovisuales se inscribieron dentro de las llamadas Plataformas Culturales, adscritas al Ministerio del Poder Popular para la Cultura a partir del 2005, y añadiendo una nueva plataforma llamada Misión Cultura. Las políticas culturales se dirigen cada vez más a la profundización de la Revolución Bolivariana, que pasa por una nueva concepción de la cultura nacional. Mientras la Misión Cultura fue creada como "proyecto bandera" para la "construcción" del "Socialismo del siglo XXI" (Bermúdez y Sánchez 562), la Plataforma del Cine y Medios audiovisuales se basó en organismos autónomos, situación que cambia posteriormente. En el 2013, el CNAC aparece en su web oficial como el “ente rector" de esta Plataforma. ${ }^{8}$ Las políticas culturales se centralizan cada vez más y la "cultura nacional" se identifica con un proyecto ideológico del Estado, lo que dificulta una posición crítica y autónoma del sujeto frente a ella. Se han reforzado posturas del siglo XX en Venezuela centradas en la búsqueda de una "identidad nacional fundada en el pasado", no sólo en los héroes de la independencia, sino en lo "telúrico", lo "propio", la defensa de "nuestros ancestros" (Bermúdez y Sánchez 549). La "dinámica étnica intercultural" surgida de los "diversos movimientos migratorios" contemporáneos en la configuración de nuestra identidad nacional, ahora se ignora mucho más que antes (Bermúdez y Sánchez 549). Sobre todo cuando se trata de la inmigración de origen europeo. La revaloración de los indígenas y los afrodescendientes tiene lugar en un marco de exclusiones históricas. ${ }^{9}$ Winthrop Wright compara a Venezuela con Brasil tanto en el orgullo por el mestizaje (componente mayoritario configurador de la nación), como en su movilidad social y racial, distante de la historia de segregación de los Estados Unidos (8-9). Sin embargo, Wright también demuestra la ambivalencia de Venezuela en su historia, en la cual la tolerancia racial ha alternado con prejuicios, discriminación e incluso racismos hacia la población no blanca, expresados no violentamente ni permitidos

\footnotetext{
8 Farrell considera el Instituto Cubano de Arte e Industria Cinematográficos (ICAIC), en tanto es un medio para difundir los mensajes de la Revolución dentro y fuera del país, un modelo de la Plataforma del Cine y los Medios Audiovisuales de Venezuela, pero establece una diferencia en que el ICAIC está organizado de forma jerárquica y centralizada, y la Plataforma se organiza a través de organismos autónomos (36). Esta situación cambia cuando el CNAC se convierte en "ente rector" de dicha Plataforma, adscrita a su vez al Ministerio del Poder Popular para la Cultura.

9 El censo del 2011 registra por primera vez el autorreconocimiento étnico de la población: 49,9\% moreno/a, 42,2\% blanco/a, 2,8\% negro/a, 0,7\% afrodescendiente y 2,7\% indígena (Mastronardi). Sin embargo, se subestima, cuando no se ignora, el origen migrante de parte de la población, así como también la diversidad de la familia venezolana, en la cual suele haber en un mismo núcleo familiar personas con piel clara, negra, morena o mestizas, y donde la diferenciación entre blanco/a y no blanco/s es flexible. Este dato es importante en un contexto en el que tiende a establecerse equivalencias automáticas entre la autorrepresentación racial o étnica y la inclinación política, lo que simplifica la diversidad y complejidad de la sociedad venezolana.
}

Revista Iberoamericana, Vol. LXXXI, Núm. 251, Abril-Junio 2015, 601-625 ISSN 0034-9631 (Impreso) 
en la ley, sino sutilmente en la vida social. Ahora el proceso se ha invertido. El rechazo sutil y a veces no tan sutil -si bien no admitido por la ley-a la inmigración de origen europeo, se hace presente en el oficialismo. ${ }^{10}$

La crispación de la polarización ha afectado la comunicación y la percepción del otro. Se oscila entre clasismo, racismo y xenofobia o se borran a veces sus fronteras. En los medios y el cine subyace esta tensión, aunque con variaciones de lado y lado. ${ }^{11}$ Bajo esta nueva orientación, la Caracas del este y la del oeste, la de los seguidores y la de los no seguidores de la Revolución Bolivariana, refuerzan sus mutuos antagonismos. Las imágenes audiovisuales de la televisión y el cine reflejan esta exasperación.

Al hablar de la incidencia de las políticas culturales en el cine nacional, no pretendo hacer un balance de los logros del Estado en materia de cine en el siglo XXI. Este balance ha sido hecho en parte por Michelle Farrell en un trabajo imprescindible, la tesis doctoral A "Revolution of Consciousness": Redefining Venezuelan National Identities Through Cinema (2011), donde se describe el funcionamiento de la Plataforma del Cine y los Medios Audiovisuales y se lo ejemplifica a través del análisis de un reducido pero representativo ejemplo de películas. ${ }^{12}$ Intento ahora abordar esta discusión desde otra perspectiva. Como observa Alexis Correia en su artículo "La producción se triplicó gracias a la Ley del Cine”, más allá de los logros de la Plataforma, el aumento de la

${ }_{10}$ Puede haber inmigrantes de ascendencia europea que apoyen al chavismo, pero las contradicciones en ese caso no dejan de asomar. Un ejemplo lo aporta Mario Silva, quien reconociendo su origen ("quiero dejar muy claro que soy hijo de inmigrantes"), se refiere a ellos en forma discriminatoria en marchas opositoras: "se ilustran las mismas caras de una clase media y alta con rasgos muy bien definidos. Blancos, casi la totalidad con herencia europea y de perfil en su mayoría, español, portugués e italiano" ("El odio a Chávez o la herencia del inmigrante"). Duno-Gottberg ve acá un ejemplo de un discurso que alienta la xenofobia ("The Color of Mobs" 293). La hojilla, programa de la estatal VTV del que fue presentador Mario Silva (2004-2013), fue una respuesta a la línea opositora de los medios privados durante el periodo 2002-2004, siendo objeto de crítica por reproducir, si no exacerbar, los sesgos de descalificación racial o política en que habían caído con frecuencia los medios privados.

11 Los sesgos racistas o clasistas en los medios privados hacia el chavismo han sido documentados por Duno-Gottberg, en el periodo conflictivo 2002-2004 ("The Color of Mobs" 272, 286-287), y si bien considera que a partir del golpe del 2002 cada lado ha tratado de ser más inclusivo hacia el otro en cuanto a sus representaciones (294), también reconoce dentro del discurso chavista discriminaciones que describe como xenofóbicas hacia la oposición en el periodo 2001-2003 (293,297). Aparte de artículos publicados en el medio oficialista Aporrea, también podrían mencionarse varias películas. El Caracazo (2005), de Román Chalbaud, estigmatiza a un canario y a un italiano como personajes acaparadores, insensibles al pueblo. En Bloques (2008), de Alfredo Hueck y Carlos Caridad, el apellido de origen vasco, Aristigueta, es el de una familia blanca, de la clase alta y corrompida. En Libertador Morales, el justiciero (2009), unos comerciantes inmigrantes portugueses son objeto de risa y burla. Esta lista es sólo ejemplificativa, no exhaustiva.

12 Agradezco a Michelle Farrell permitirme leer esta tesis doctoral, así como por referirme el artículo "Plataforma del Cine y Medios Audiovisuales exhibirá 12 títulos de cinematografía venezolana" de Correo del Orinoco. 
producción anual de películas debe mucho a la Ley de cine del 2005 (producto de varias décadas de luchas de cineastas, anteriores a la era chavista). Una exhibición selecta realizada en el 2012 muestra, sin embargo, que dentro de la variedad de tendencias temáticas y estéticas no sobresalen películas de una crítica abierta que pueda incomodar a la Revolución Bolivariana ("Plataforma del Cine"). El cine crítico o contrario al oficialismo ha sido escaso, ${ }^{13}$ lo que contrasta con el cine producido, no sin algunas censuras, durante las últimas tres décadas del siglo XX ${ }^{14}$ Llama la atención en cambio, el número de películas que exaltan los valores de la Revolución Bolivariana. Me interesa a continuación describir, desde la teoría, cómo este campo de luchas se ha desplegado desde propuestas alegóricas en el cine venezolano, para finalmente analizar cómo se construye la alegoría política en Des-autorizados.

\section{Alegorías políticas en el Cine Venezolano del Siglo XXI}

En la Venezuela contemporánea es frecuente el uso de alegorías políticas, desde la telenovela hasta el cine e incluso la literatura. Respecto a esto último, Miguel Gomes, en su análisis sobre la presencia de la alegoría en algunas obras de la nueva narrativa venezolana, dice: "En este momento, cuando las prácticas alegóricas se perfilan como posibilidad de lectura [...] muchos elementos presentes en la historia empiezan a articularse como red de significados sociales" (827). Mediante la alegoría se dice una cosa con la palabra y otra cosa distinta con su significado, según la definición clásica de Quintiliano (274). La alegoría es también un modo polémico de lectura de un texto (verbal o visual) que al desplazar la significación más allá de un nivel literal o formal puede servir tanto para ampliar los significados como para estabilizarlos y constreñirlos. Bien dice Elana Gomel: "Paradoxically, allegory appears both open and closed, both authoritarian and libertarian, both flexible and rigid" (89). Podemos dar un paso más en esta interpretación política de la alegoría, acercándonos a ella a través del psicoanálisis. Freud nos da la clave al describir la "deformación" que ocurre en un sueño de realización de deseos cuando asoma en él la tendencia opuesta y entonces el

13 Secuestro express, de Jonathan Jakubowicz (2005), fue objeto de una enconada demanda legal por parte del Estado por incluir imágenes sobre el 11 de abril de 2002 de mucha circulación en los medios, lo que motivó la salida del director del país. Recientemente, las películas Esclavo de Dios (2013), de Joel Novoa, y Pelo malo (2013), de Mariana Rondón, han sido objeto de descalificaciones públicas en medios y redes sociales afines al chavismo por considerar que ambos directores expresan ideas contrarias al oficialismo.

14 Se enumeran de un modo no exhaustivo trece películas de este periodo con un "juicio crítico en torno a la violencia que ejerce el "sistema" sobre los venezolanos, sin importar la clase social" (Filmografia venezolana 8). La lista podría ampliarse con películas que denuncian la corrupción ya sea de la justicia o entes del Estado, como Cangrejo I (1982) y II (1984) de Román Chalbaud, y Ledezma, el caso Mamera (1981), de Luis Correa, censurada.

Revista Iberoamericana, Vol. LXXXI, Núm. 251, Abril-Junio 2015, 601-625 ISSN 0034-9631 (Impreso)

ISSN 2154-4794 (Electrónico) 
deseo sólo puede manifestarse "encubierto y disfrazado", fenómeno que en seguida Freud asocia a la vida social, cuando el miedo a la censura, en situaciones frágiles, conduce a la estrategia de alusiones, de indirectas, de disfraz (209).

Friedric Jameson ve la "alegoría política" como la expresión de contradicciones sociales reprimidas que asoman en el texto cultural (encuéntrese en la "alta cultura" o en la cultura de masas) (79-80). Entonces será necesario, advierte Jameson, identificar su estructurante dialogismo, en el sentido de Bajtin, su característica polifonía donde siempre encontraremos voces antagónicas, contrapuestas. De allí la paradójica atracción de Jameson por Northrop Frye. El estructuralista canadiense consideraba el romance como un modo narrativo que polariza la experiencia bajo una tendencia dual, aparentemente ideal y constante, como los ciclos de la naturaleza (el bien y el mal, la noche y el día, la vida y la muerte). Jameson afirma que incluso en el melodrama -una versión del romance- subyacen conflictivos discursos sociales, reapropiaciones de formas o discursos populares y, por tanto, complejas alegorías políticas (86-87).

Es en este marco donde debemos insertar la reflexión sobre el cine venezolano en el siglo XXI. Este ha contado con alegorías políticas y melodramas desde el siglo $\mathrm{XX}$, pero su orientación ha cambiado. Estas alegorías se pueden diferenciar por su apoyo o distanciamiento crítico a la Revolución Bolivariana, pero en los dos casos las implicaciones son diferentes. En su tesis doctoral Michelle Farrell describe las películas Libertador Morales, el justiciero (Efterpi Charalambidis, 2009), Macuro, la fuerza de un pueblo (Hernán Jabes, 2008), Miranda regresa (Luis Alberto Lamata, 2007) como "ficciones fundacionales", siguiendo a Doris Sommers, ya que en ellas el amor y la política, lo privado y lo público se entrelazan, proponiendo una nueva narrativa de la nación acorde con el proyecto político de la Revolución Bolivariana, tendencia que puede encontrarse en muchas películas alegóricas de la productora estatal Villa del Cine (110-111). Me detendré en cómo opera la alegoría política en Libertador Morales, el justiciero, que destaca los valores de la Revolución Bolivariana, para luego ver más adelante cómo su estructura contrasta con la alegoría política en Des-autorizados, no obstante ambas se sirven del melodrama.

Libertador Morales, el justiciero es una historia que combina una estructura melodramática con referencias alegóricas a la realidad política de Venezuela en la era chavista. Es relevante por su acogida exitosa en el público, como recuerda Farrell, quien también acierta al resaltar la importancia de los tatuajes (de Libertador y su hijo Simón) y los murales del centro de Caracas, ambos con mensajes bolivarianos, como marcas del cuerpo de la nación en este periodo (138-139). Libertador Morales, el justiciero en su densa intertextualidad contiene en muchos aspectos de su trama ideologemas de la Revolución Bolivariana. En un episodio, Libertador intenta detener un robo que está por suceder, los ladrones lo descubren, lo golpean y Libertador regresa desmoralizado a su casa. Mientras la madre cura sus heridas, Libertador nos da la espalda, y un zoom

Revista Iberoamericana, Vol. LXXXI, Núm. 251, Abril-Junio 2015, $601-625$ ISSN 0034-9631 (Impreso) 
de la cámara nos revela un tatuaje de la bandera de Venezuela a la espalda de Bolívar montado en su caballo (Farrell 138), como en un juego de espejos. La madre que cuida sugiere las penurias de la Madre Patria por los sufrimientos de su hijo, Libertador, actualizándose en el presente una genealogía heroica decimonónica. No menos importante es otra escena donde la cámara capta un brazo de Simón mientras duerme y leemos un tatuaje: "Justicia", que recuerda las citas que mezcla Libertador Morales con la imagen de Bolívar en su moto (Farrell 139). Por último, en un encuentro erótico con Daisy, esta descubre el tatuaje de Bolívar en la espalda del Libertador Morales, motivo de risa, pero no en son de burla, sino de afecto, en este contacto íntimo previo a la sugerida consumación del acto sexual. El Bolívar del chavismo se inscribe así en el cuerpo de la nación, en sus sueños, en sus deseos.

Acá pueden servirnos los análisis de Lévi-Strauss del arte facial de los indígenas Caduveo, quien describe cómo esta forma de arte corporal, expresión de sueños y de imaginarios, configura una resolución simbólica a contradicciones sociales no solucionadas en la realidad; Jameson ve en este "texto visual" un ejemplo elocuente del inconsciente político (79-80). En Libertador Morales, el justiciero, los tatuajes corporales como marcas de sueños y deseos de esas contradicciones encarnan, de un modo inesperado, la emergencia de un nuevo y ubicuo relato nacional. Pero en este relato ya la figura de Bolívar no es unificadora sino divisoria: ser bolivariano en este contexto es serlo desde la interpretación que le da el chavismo, no serlo es no ser venezolano o ser ajeno al cuerpo social. ${ }^{15}$ En la película las discusiones del Consejo Comunal son determinantes. ${ }^{16}$ Al principio irrumpen los conflictos entre una mujer de piel oscura con camisa roja, ${ }^{17}$ que vindica la elección por "voto popular" de Chávez, mientras una opositora de piel blanca la rechaza irracionalmente. También hay inmigrantes de origen europeo, pero son ocasión para escenas cómicas, de burla. No se profundiza en la complejidad étnica del país sino que se la simplifica en dos polos y a la larga sus diferencias desaparecen. El liderazgo final lo asumirá Libertador Morales, pasando de ser ex policía a Comisario de la parroquia. ${ }^{18}$ La ubicuidad de Bolívar y la centralidad de Libertador Morales dan poco

\footnotetext{
15 Según la oposición civilización-barbarie, la película retomaría este antagonismo en un marco populista: "With this reading, to be against Bolivarianism is to be against Bolivar and the fabric of the Venezuelan body and urban center. Opposing this common binary populist discourse opposition would be unVenezuelan" (Farrell 139).

${ }^{16}$ El chavismo se nutrió de experiencias de democracia participativa que lo precedieron en Venezuela y que quedó plasmada en la Constitución de 1999, sin eliminar la democracia representativa. Los Consejos Comunales, concebidos en principio para incrementar la participación, han tenido un efecto contrario.

17 Es el color con que se identifica el chavismo y que el gobierno reproduce en uniformes oficiales, organismos y lugares públicos.

18 Libertador Morales, miembro asistente al Consejo Comunal y correlato de Hugo Chávez, termina al final siendo un líder cuya figura opaca al Consejo Comunal.
}

Revista Iberoamericana, Vol. LXXXI, Núm. 251, Abril-Junio 2015, 601-625 ISSN 0034-9631 (Impreso) ISSN 2154-4794 (Electrónico) 
espacio a la diversidad dentro del Consejo Comunal. ${ }^{19}$ Estas oposiciones binarias no son exclusivas de esta película en el cine venezolano de este periodo (Farrell 207), sino que son un reflejo de la polarización. Importan para contrastarlas luego con la alegoría política en Des-autorizados como tentativa imaginaria de trascender la polarización desde las huellas de otro relato nacional, presente como subtexto.

\section{DES-AUTORIZADOS Y DESECHADOS: UNA ALEGORÍA EXISTENCIAL}

Schneider ha declarado que "Des-autorizados es como extender mi teatro hacia el cine" ("Encuentro con Elia Schneider"). También ha confesado que en la selección de los lugares de Caracas ha procedido más bien por intuición, a menudo como un "trabajo inconsciente que sólo entiendo luego, cuando analizo por qué escogí tal locación o tal ángulo", por eso reconocerá después que El Parque El Calvario o el Hotel Humboldt están en la película pues fueron muy visitados durante su infancia ("La Caracas de Elia Schneider"). Tanto su trayectoria teatral como una Caracas autobiográfica traslucen en Des-autorizados. Ambos elementos, el teatro y el paisaje urbano de una Caracas de la memoria, se alían en la primera secuencia, que semeja un preámbulo. Un plano general revela el exterior de un monasterio abandonado y deteriorado de El Parque El Calvario, y una mujer coloca la aguja sobre un tocadiscos, antes de entrar bailando con la música que empieza a sonar al interior del edificio. Ella es parte del trío de las Deses3sadas, quienes cantan y bailan la canción Besos, besos con una gestualidad camp: desenfadadas, llevando pelucas de colores, vestidos de los años cincuenta y moviendo los brazos y las piernas al estilo de una música pop. En este lugar vive y escribe Elías, el bohemio inspirado en su musa ideal Nina, pero ese mundo ideal se viene abajo. En un momento de crisis, lanza las páginas escritas al vacío, acto que imitan las Deses3sadas en esta primera secuencia, que funciona a modo de flashforward y sugiere cómo se mezclan acá melodrama y comedia. Tanto el recurso de marcas no convencionales, comentarios de la acción, distintivo autoral del cine de arte y ensayo (Bordwell 211), como el distanciamiento, indicaciones que Brecht usaba en el teatro para eludir el efecto de "ilusión" y hacer permanecer al espectador lúcido y crítico, conforman desde el principio el discurso cinematográfico.

19 La ley Orgánica de los Consejos Comunales, de 2009, dice que su finalidad es trabajar en la construcción del modelo socialista, no presente en la Constitución nacional (López Maya, "Conversaciones" 48-49). Sus recursos dependen de la Presidencia, quitando así a las organizaciones populares la autonomía que antes tenían. El modelo económico gira aún más que antes en torno a la redistribución de la renta petrolera y hay corrupción en la entrega de recursos a los Consejos Comunales (72). Aunque 48\% de familias vivían en la pobreza al inicio del chavismo y hoy estas se calculan en 29\%, López Maya considera ese logro insuficiente (53), y, en vista de su dependencia de la renta petrolera y su bonanza temporal, a la larga insostenible (54-56).

Revista Iberoamericana, Vol. LXXXI, Núm. 251, Abril-Junio 2015, 601-625 ISSN 0034-9631 (Impreso)

ISSN 2154-4794 (Electrónico) 
La canción Besos, besos (así como las letras de todas las canciones) puede interpretarse como la presencia ubicua de las convenciones melodramáticas con las que la cultura de masas ronda desde Hollywood hasta la telenovela en Venezuela. Des-autorizados no es la excepción, recordemos que el nombre del productor es Oscar, pero ya la letra de Besos, besos anuncia un giro "a modo de parodia". El cine venezolano tampoco es completamente ajeno a estas convenciones, pues además de una atracción intermitente por la telenovela venezolana (King 223), no ha renunciado del todo a la seducción de la estética de Hollywood, de un impacto masivo más inmediato, tratando, sin embargo, de redireccionar estos códigos con un propósito político. Así ha sucedido con cierto cine social a partir de 1970 (Rísquez 166) y en algunas películas de la Villa del Cine (Farrell 61). Des-autorizados se enmarca en un campo de luchas entre el cine, por un lado, y los medios de comunicación, la cultura de masas y el poder político, por el otro, de cuyas tensiones polarizantes en Venezuela he hablado anteriormente. Una circunstancia muy ilustrativa de esta lucha en la película es la del personaje Bruno Da Mata, quien compra la obra de Elías para poner el arte al servicio de sus propios intereses. Por eso le impone la orden de modificar su obra, dándole más "color" melodramático, adaptándola a un consumo masivo. Las protestas de Elías de nada valen; Da Mata, como jefe de una mafia, negocia con importación de prótesis, con objetos, y el arte para él se convierte también en un mero objeto para hacer negocios, ajeno a los sujetos. Bruno Da Mata, ha dicho Schneider, hace pensar en "[...] las cadenas que tienen los artistas frente a la sociedad: los escritores van, escriben, se lo dan a los directivos del canal y ellos dicen: 'Yo necesito meter los productos'. Son los Bruno Damata: 'Búscame la miss y no el actor'. Eso hace que muchas veces que las obras sean reflejo del encadenamiento que tenemos" ("Encuentro con Elia Schneider y su nueva película Des-autorizados").

Pero esas cadenas del artista frente a la sociedad no se dan sólo en los medios privados en Venezuela. Hemos visto también que el Estado puede ejercer control sobre los contenidos. Por eso Schneider ha sido muy crítica con el Reglamento Interno de Estímulo y Fomento a la Creación y la Producción Cinematográfica, aprobado por el CNAC (Centro Nacional Autónomo de Cinematografía) en el 2012, con el apoyo de la mayoría de los cineastas consultados, el cual establece ciertos controles sobre el guión de la película. ${ }^{20}$ Schneider aclara: "Si bien cuando filmamos la película Des-autorizados este reglamento aún no se había aprobado, ya en los gremios y en la institución se hablaba de que esto se venía [...]" (Entrevista personal 15 de noviembre de 2012). La

${ }^{20}$ El artículo 30 establece que si se llegara a realizar cambios en el guión, el beneficiario del contrato de estímulo económico debe notificarlos a través de un "Productor Delegado", designado por un Comité Ejecutivo. Este último deberá aprobar o no dichos cambios. Realizar una modificación sin esta aprobación será causal de resolución del contrato. Este Reglamento, sin antecedentes en la historia del cine venezolano, traduce una de las encrucijadas problemáticas entre Estado y libertad creativa que vengo analizando.

Revista Iberoamericana, Vol. LXXXI, Núm. 251, Abril-Junio 2015, 601-625 ISSN 0034-9631 (Impreso)

ISSN 2154-4794 (Electrónico) 
fiscalización y control del guión de Elías, secuestrado por los esbirros de Bruno Da Mata, sería también una señal en esta dirección. Schneider, quien ya fue fiscalizada y censurada por su película Huelepega: ley de la calle, durante el segundo gobierno de Rafael Caldera, es crítica también de las políticas culturales implementadas durante el gobierno de Chávez a través de la Plataforma del Cine y Medios Audiovisuales. Para Schneider cualquier intromisión del Estado en la libertad creativa del artista es peligrosa. Nos lleva de nuevo a la metáfora del desecho en Elías: si la obra es controlable, manipulable, la obra deja de ser, su creador deja de existir. Es humanamente indiferente, convertible en desecho.

La escena que sigue a lo que he llamado el preámbulo en Des-autorizados resalta al mismo tiempo la vulnerabilidad y el protagonismo de los creadores. Un plano general nos muestra en el fondo a la multitud de los personajes de la película, a cierta distancia detrás de Elia, quien se destaca en el centro en un plano medio, en la avenida Boyacá, conocida como la "Cota Mil", sentada en un escritorio frente a su computadora (fig. 1). Su voz narradora medita sobre la creación y la intempestiva libertad de sus personajes, quienes se acercan hacia ella, la cámara y el espectador, caminando en dirección del este hacia el oeste, pero en el canal contrario, ya que la dirección este-oeste de la avenida está al lado de la montaña. ${ }^{21}$ Su voz aparece en over/off a lo largo del film. ${ }^{22}$

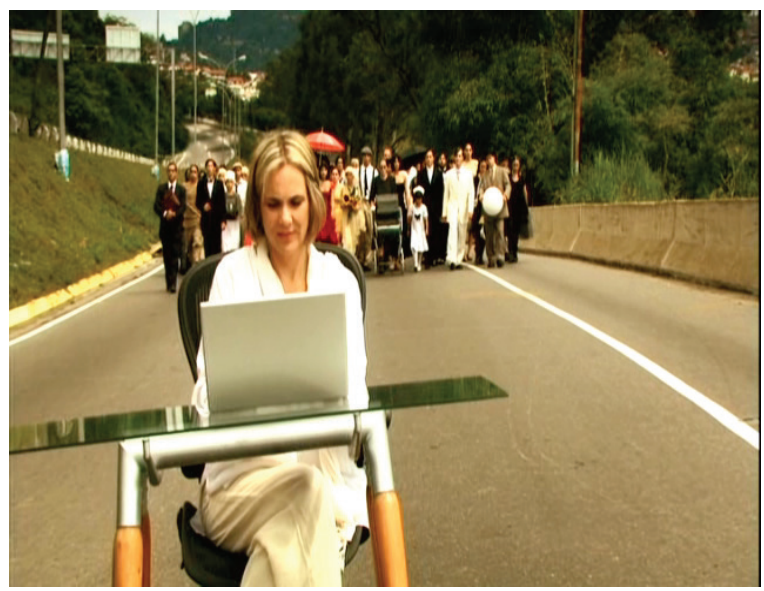

Figura 1

${ }^{21}$ Agradezco a Wladimir Romero y Gustavo Valle por su colaboración en la identificación de los lugares de Caracas en Des-autorizados.

22 Voz en over no es igual a voz en off, esta última está sólo ausente de la cámara, la primera en cambio proviene del tiempo y el espacio del discurso (Kozloff 3), sin embargo, ambas pueden llegar a solaparse o confundirse (6). Así sucede en Des-autorizados. Elia es autora, narradora, personaje, que aparece y

\footnotetext{
Revista Iberoamericana, Vol. LXXXI, Núm. 251, Abril-Junio $2015,601-625$ ISSN 0034-9631 (Impreso) 
Se subraya así una estética irreverente, carnavalesca, a contracorriente. Pero esta escena recuerda también la primera parte de Huelepega: ley de la calle, cuando Oliver, el niño protagonista, camina desamparado por una avenida de Caracas, aunque el comienzo de Des-autorizados es en tono de comedia. Esto cambia cuando más adelante nos encontramos con un basurero, una marca autoral pues los desechos aparecen en sus tres primeros largometrajes. Las páginas del guión que lanza Elías por la ventana son recogidas en la calle alegremente por las Deses3sadas, como agentes de una sociedad de consumo donde el desecho de productos es una rutina mecánica y las depositan en un camión que emprenderá el recorrido hasta el basurero. La obra es un desecho y también lo es metonímicamente la vida de Elías, comprable y desechable. El desecho tiene una carga no sólo estética y política, sino una existencial más profunda en la memoria de Schneider, hija de sobrevivientes del Holocausto. La imagen del desecho conecta psíquicamente las injusticias sociales de la sociedad venezolana contemporánea con las de la Segunda Guerra Mundial y el Holocausto: "Para mí el basurero es una imagen apocalíptica, más bien de la guerra, de la intolerancia, del desecho, de muchas cosas que uno puede ver sino ahí. Es lo último, lo que nosotros no vemos, que está tapado" ("Encuentro con Elia Schneider y su nueva película Des-autorizados").

Lo “tapado" subraya de nuevo lo que está detrás de la superficie política y psíquica de la sociedad, allí podemos encontrar varias capas de realidades, de recuerdos, conscientes o inconscientes. La violencia de los niños de la calle en Huelepega: ley de la calle despertó en Schneider otra violencia más cercana a ella: "Yo tenía que hacer esta película, porque si pasaba enfrente de mí y no decía nada, era como si pasara el Holocausto y hablara de las flores y frutas" ("Nuevos rostros" 98). Por eso más allá de los niños de la calle, más allá de las críticas a los gobiernos de Caldera y Chávez, el Holocausto es en Schneider un recuerdo de luchar y no claudicar ante situaciones que ponen en riesgo la libertad o la vida. ${ }^{23}$ Así, al comentar la escena de Elia en el medio de la Cota Mil en Des-autorizados y su vulnerabilidad a que sea arrollada por un camión, comenta: "todo es cuestión de sobrevivir y resistir. (El Holocausto está siempre presente)" (Entrevista

desaparece, pero su voz es representada por una conocida y joven locutora y animadora de los medios privados, Jean Mary (ver créditos finales). La ironía de Schneider es vertiginosa, siempre hay algo al margen de las cámaras, de lo que la voz o las imágenes narran. Más allá del escepticismo, la película al final subraya la responsabilidad del espectador: "a ti que estás mirando, habrá que ver qué hacemos con todo esto".

${ }^{23}$ En otro momento aclara: "el abuso del poder, la ignorancia unida a la arrogancia es la semilla que luego germina y desarrolla estos procesos de autoritarismo, fascismo, exceso de poder o llámale H.Y no es que Caldera o Chávez sean Hitler, son diferentes empaques pero adentro la esencia, la semilla, es igual" (Entrevista personal, 4 de diciembre de 2013). Aunque resulte controvertida esta comparación, es matizada y nace de una experiencia muy personal. No debe confundirse con las descalificaciones recíprocas entre oficialismo y oposición.

Revista Iberoamericana, Vol. LXXXI, Núm. 251, Abril-Junio 2015, 601-625 
personal, 1 de septiembre de 2012). Pero para Schneider su pasado como judía y como caraqueña no se divide, todo se conecta en su cine, en sus recuerdos y reflexiones. ${ }^{24}$

\section{DEL ESPACIO IMAGINARIO AL ESPACIO SOCIAL}

La cita de Huelepega: ley de la calle en Des-autorizados nos lleva, a través de la ficción, a considerar la configuración de un nuevo espacio social durante la Revolución Bolivariana. El basurero -el desecho- es un destino del que huyen los personajes de Elías por Caracas, pero al recorrerla vuelve, como un pasado reciclado. En el parque El Calvario (nombre y lugar emblemático), desde el monasterio en ruinas donde vive, Elías lanzará al vacío las páginas de su manuscrito que irán a dar en el basurero de donde emergerán Nina y Federico (fig. 2). Como estos personajes continuarán luego un recorrido por Caracas en la que aparecerán sus contrastes sociales y pobreza, pero de un modo muy leve, como quien levanta apenas el telón, conviene analizar el imaginario social subyacente. Para ello, debo volver al primer largometraje de Schneider.

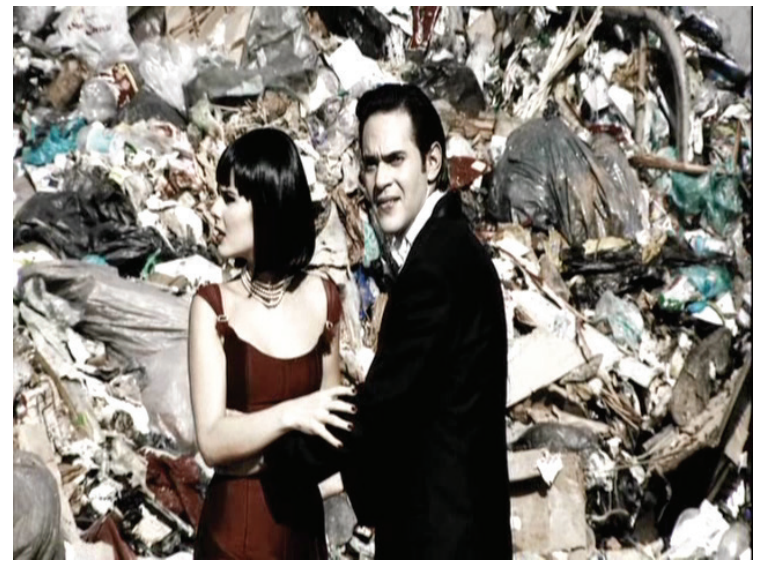

Figura 2

Estrenada en 1999, Huelepega: ley de la calle comienza con unas líneas que denuncian con cifras la pobreza, la violencia y las muertes que sufren los niños, un problema que en los últimos cuarenta años no han logrado resolver, a pesar de ser Venezuela uno

${ }^{24}$ Como parte de estas precisiones, la directora añadió al comentario de la nota anterior: "Y por supuesto estoy de acuerdísimo [...] cuando dices que soy 'sobreviviente indirecta' y que las situaciones de riesgo de perder la libertad se remiten a lo que sucedió, pero no te olvides que mi imaginario se nutre también de los estímulos del día a día y las reflexiones que estos generan en mí. Y este día a día lo viví en Caracas, no en París" (Entrevista personal, 4 de diciembre de 2013).

\footnotetext{
Pevista Iberoamericana, Vol. LXXXI, Núm. 251, Abril-Junio 2015, $601-625$ ISSN 0034-9631 (Impreso)

ISSN 2154-4794 (Electrónico)
} 
de los países latinoamericanos más ricos. Esa riqueza es la del Estado petrolero y ese periodo se refiere al Pacto de Punto Fijo. La convergencia entre Estado, democracia y petróleo produjo beneficios sociales y educativos, pero degeneró luego en la mala administración de las élites gobernantes a partir de la década del setenta (época del boom en los precios del petróleo), trayendo a la larga una acentuada desigualdad y violencia social en la última década del siglo. Huelepega: ley de la calle cierra en cierto sentido el ciclo de cine de denuncia de la pobreza infantil ante un Estado petrolero millonario e indiferente, ciclo que inicia con Soy un delincuente, de Clemente de la Cerda (1976). Tanto Guillermo Barrios (77-78) como Luis Duno-Gottberg (51) coinciden en destacar la importancia del inconcluso y gigante Helicoide de Roca Tarpeya, que contrasta con la pobreza de los ranchos o favelas de Soy un delincuente, como un emblema del fracaso de nuestra modernización. Sus análisis sobre la representación de los recorridos urbanos de Caracas en el cine venezolano como unos profundos referentes semióticos sobre nuestra problemática modernización son también pertinentes. ${ }^{25}$

En esta discusión entran las ideas de Henri Lefebvre, para quien el espacio es a la vez producto y generador de las relaciones sociales, la tierra como propiedad y las fuerzas productivas intervienen en esas relaciones, la naturaleza es la materia prima del espacio social (85). Coronil lleva este análisis de Lefebvre a la historia venezolana, mostrando la interacción entre la naturaleza (petróleo), el Estado y la sociedad, que se inscribe a su vez en los "cambiantes realineamientos internacionales", como los del Primer y Tercer Mundo (71). En la órbita de estas reflexiones y siguiendo también a Lefebvre, Duno-Gottberg expone las implicaciones de las representaciones del espacio social en Soy un delincuente, cuya trama gravita en torno a la presencia perturbadora del inconcluso Helicoide de Roca Tarpeya "como símbolo importante del fracaso del proyecto modernizador emprendido por Marcos Pérez Jiménez en la década de los cincuenta" (51). En este periodo, el dominio de la naturaleza bajo el impulso del Estado petrolero da paso a la construcción de la autopista Caracas-La Guaira, así como al lujoso Hotel Humboldt ubicado en el Ávila y accesible desde el Teleférico (González Casas y Marín 18-19).

Estos signos heredados de un proyecto modernizador autoritario y sus contradicciones entre riqueza y pobreza reaparecerán en Des-autorizados. Cuando Nina y Federico emerjan del basurero, ansiosos por encontrar un destino "auténtico", lo que encontrarán

${ }_{25}$ Duno-Gottberg considera como "alegorías políticas" a Soy un delincuente y Secuestro express por su tratamiento del "espacio cinematográfico" ("Geografías del miedo", 59-60). Secuestro express exacerba la visión de una "nación polarizada" (56), que demarca el territorio entre "gente buena" del este y gente peligrosa del oeste. Sin embargo, otras películas como Libertador Morales...reproducen esa misma dinámica, aunque invirtiendo ahora geográfica y sutilmente el polo positivo y el negativo. Des-autorizados propone una crítica de este antagonismo polarizante como única forma de relacionarse socialmente con Caracas y también con el país.

Revista Iberoamericana, Vol. LXXXI, Núm. 251, Abril-Junio 2015, 601-625 ISSN 0034-9631 (Impreso)

ISSN 2154-4794 (Electrónico) 
es, después de varios recorridos y extravíos, un Hotel Humboldt solo y hace tiempo clausurado, en cuyo espacio no podrán permanecer (fig. 3). Nina abandona a Federico al saber que le ha sido infiel, incapaz de distinguir entre Nina y Raquel (la actriz que la representa en el montaje de Amantes sin destino), a quien él consigue en el Teleférico y asciende con ella hacia las alturas, evadiéndose de la realidad. Las ilusiones de autenticidad son tan artificiales como los cimientos sobre los que está construido el proyecto modernizador del Hotel Humboldt.

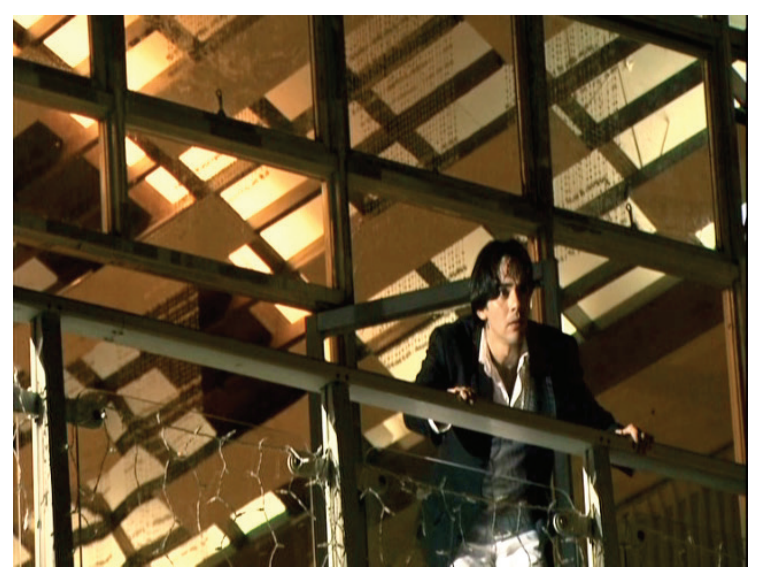

Figura 3

En otro de los giros metaficcionales, Nina descubrirá a la actriz Raquel en el Hotel Humboldt. La obra comprada por Bruno Da Mata se representará en el teatro que pertenece a él también, contando además este "mecenas" con su aliado, el militar Vincent. Pero Nina no se siente representada en Raquel, quien, aunque no le gustaba al principio el cambio que dio Elías al guión, termina por conveniencia adaptándose a él y al poder. Raquel se va de la mano de los triunfadores, mientras Nina regresa derrotada junto al también derrotado Elías.

Pero este fracaso ya se presentía antes. Los mismos lugares en donde se desarrolla la trama lo anunciaban. Ya vimos cómo El Calvario y el Hotel Humboldt son asociados a recuerdos de infancia, forman parte de una estructura afectiva, pero más allá de la nostalgia, importa resaltar cómo ya en el propio momento de filmarlos están pasando por un proceso de resemantización. Ambos lugares han estado vinculados a militares. El primero fue renombrado bajo el presidente Antonio Guzmán Blanco con su nombre (a finales del siglo XIX) aunque dejó de llamarse así más tarde. El Parque El Calvario contiene el Arco de la Federación (bajo el que pasan en una escena Nina y Federico, felices, antes de su crisis final), construido por el presidente Joaquín Crespo, en

\footnotetext{
Revista Iberoamericana,
ISol.
} 
homenaje a la Guerra Federal (otro acontecimiento militar). En el 2010, año en que se estrena Des-autorizados, Chávez decreta que El Parque El Calvario pase a llamarse Parque Ezequiel Zamora, líder militar de la Guerra Federal, muy presente dentro del discurso del presidente. El Hotel Humboldt fue abandonado en el siglo pasado, como el Helicoide (ambos emblemas de la dictadura). Se ha rescatado en la era chavista, mientras se renombró al Teleférico que accede a él.

Pero no sólo el pasado se está remodelando, también el presente está cambiando la faz de Caracas y la nación. Cuando Nina y Federico se recuperan del basurero donde fueron desechados, vuelven a la ciudad y los vemos salir del Parque El Calvario, pasando por el Arco de la Federación (fig. 4). Perseguidos en el recorrido por Vincent, la pareja entra en un descapotable por un túnel que dice en su parte superior "MTC [Ministerio de Transporte y Comunicaciones] 1977'. Al adentrarse en él, se oyen voces confusas en la oscuridad y al salir, Nina y Federico se descubren visualmente deformados, ella con peluca roja y lentes oscuros, él con los pelos de punta y el traje alterado, como unos personajes de cartoon indefinidamente moldeables (fig. 5). La cámara deja ver en un extremo del encuadre, apenas perceptible, una propaganda política en la pared del MVR, Movimiento Quinta República, partido político con que Chávez llega al poder. Los personajes en su huida desorientada han arribado a la época contemporánea de la Revolución Bolivariana.

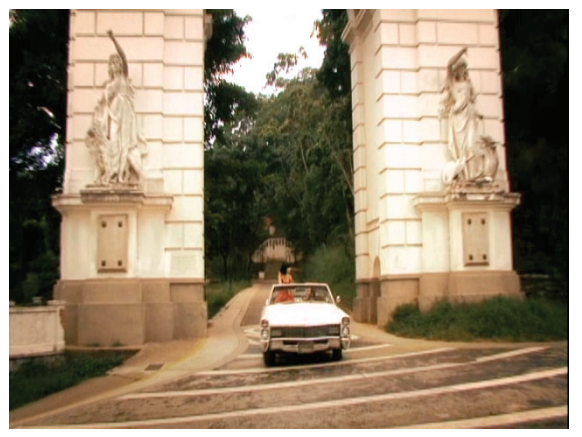

Figura 4

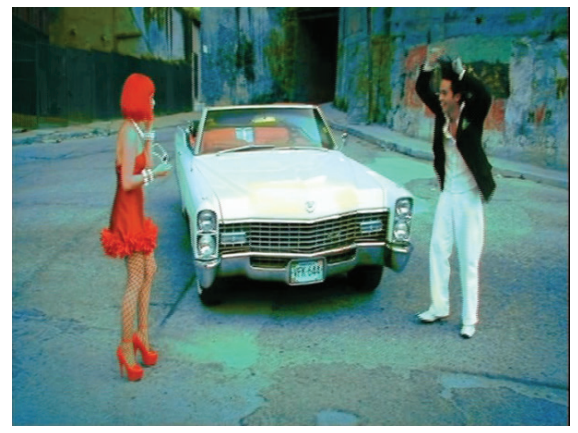

Figura 5

En este tránsito por el túnel de la historia, "MTC" y "MVR" son claves sutiles en torno al antes y el después de la emergencia del chavismo. El MTC vino a sustituir en 1977 al secular MOP (Ministerio de Obras Públicas), liquidado en 1975, buscando la descentralización (Cilento 48-49). Sin embargo, esto originó ineficiencias que llevarían a la postergación, desde 1988, de la construcción de una vía alterna al Viaducto No. 1 de la autopista Caracas-La Guaira y a su final colapso en 2006, a pesar de estudios que lo advertían, confirmando el deterioro nacional de la vialidad con más de mil puentes

Revista Iberoamericana, Vol. LXXXI, Núm. 251, Abril-Junio $2015, \quad 601-625$
ISSN 2154-4794 (Electrónico) 
en estado crítico (Cilento y Martín 21-23). Cuando Federico pierda a Nina y la busque desesperadamente por distintas vías, acabará, sin salida, frente a un paisaje ruinoso que recuerda el derrumbe del Viaducto. El colapso ya en ciernes del proyecto de modernización se acentúa en la Revolución Bolivariana, en medio del deterioro de la infraestructura vial, servicios y calidad de vida, sumado a políticas sociales clientelares. En otro sentido, la escena del tránsito por el túnel, con su cambio de nombres de la "Cuarta" a la "Quinta República", alude a una estrategia de resemantización practicada consecuentemente por la Revolución Bolivariana desde el renombramiento de la República misma hasta el de lugares y organismos públicos, con el propósito de legitimar una nueva identidad nacional, que supuestamente rescataría así a los olvidados y excluidos de la historia (Avendaño 155-156). A la larga, puesto que los nombres tienen una clara orientación ideológica, y en ese renombramiento los militares destacan, visibilizan otra forma de exclusión.

\section{“LO DEJAMOS EN VEREMOS”: AlegORÍAS DEL SILENCIO}

La conciencia intolerable de haber contribuido, bajo presión, a la escritura de una obra que sabe falsa, lleva a Elías a quemar los libros de sus lecturas y también lo escrito por él. Se ve entonces acosado por los fantasmas de los libros y de sus personajes, pero sobre todo por un militar que tiene una capucha que cubre su rostro, hasta que al acercarse a Elías se descubre: es Vincent, cuya condición de doble viene reforzada por el hecho de ser representado por el mismo actor Erich Wildpret. Pero Schneider postula más de un final. Por una especie de giro mágico, la película retrocede al momento en que se está suicidando Elías y por un azar se salva al borde de la muerte. Se libera entonces de su desencanto y decide salir a la calle. Deja su habitación de El Calvario y se dirige hacia la "Cota Mil", para reunirse por primera vez con Elia, completándose el plano con el que empezó la película. Los personajes que venían a la espalda de Elia ahora siguen su camino por delante de ella, como si la película volviera a empezar. Elia y Elías sonríen y callan por un instante. No sabemos qué va a pasar. ${ }^{26}$ Una última reflexión de la voz narradora se dirige al espectador: "a ti que estás mirando, habrá que ver qué hacemos con todo esto". Sobre la película gravita la incertidumbre estética y política insinuada al comienzo y subrayada al final.

Revisemos lo que significa ese ir contra la corriente de Elia y sus personajes al principio, en medio de una avenida y en sentido contrario de la vía. La imaginación delirante y surrealista no excluye una referencia al espacio social. El este y el oeste de Caracas son una presencia recurrente a lo largo de la película. Cuando Nina y Federico

${ }^{26}$ Así lo interpreta Schneider: "Es ahí que le damos la posibilidad a Elías y a las circunstancias que lo rodean para que aprendan de la experiencia, y cambien, pero no sabemos qué va a suceder, lo dejamos en ¡veremos!” (Entrevista personal, 1 de septiembre de 2012). Y ciertamente la obra no tiene resolución.

Revista Iberoamericana, Vol. LXXXI, Núm. 251, Abril-Junio 2015, 601-625 ISSN 0034-9631 (Impreso) 
logran sobrevivir al basurero, los vemos reaparecer en un viejo puente que une la avenida Sucre de Catia con los bloques ${ }^{27}$ del 23 de enero (vistos al fondo), cerca de la estación de metro Caño Amarillo (fig. 6). Mientras Nina y Federico caminan sobre el puente, el metro se ve venir de la estación, en dirección oeste a este. Direcciones contrarias que se entrecruzan, como al principio: el metro va hacia el este y los personajes van en dirección opuesta al metro. Más adelante, cuando pasean en un descapotable, atraviesan una autopista que descubre al fondo unos cerros, y por un momento puede ser tanto Antímano (oeste), como Petare (este), ya que en ambos lugares convergen autopista y barrio popular (fig. 7).

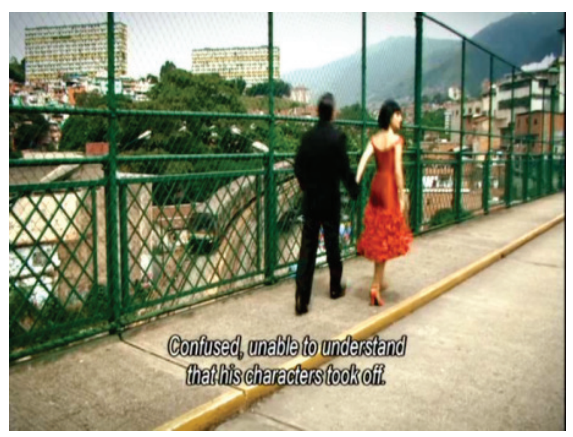

Figura 6

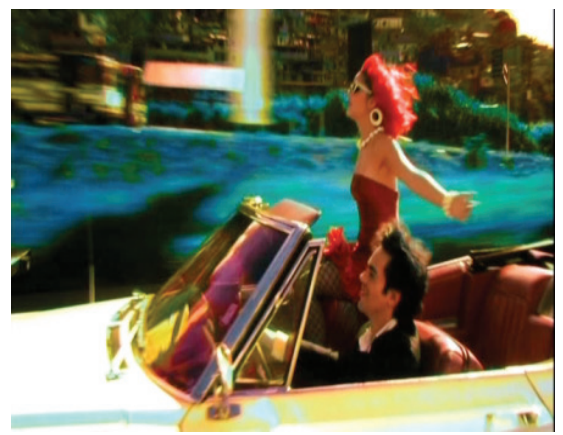

Figura 7

Nina se levanta de pie sobre el descapotable con los brazos abiertos para sentir el viento y el espacio en su cuerpo, como en sensación de recorrer libre y placenteramente la ciudad. La relación entre Nina y Federico es transgresora, pues Nina está casada con el militar Vincent. Su deseo es doblemente transgresor: más allá del poder militar que los divide, más allá de las territorializaciones de la polarización política, expresadas geográficamente en el antagonismo entre este y oeste. Sin embargo, este deseo transgresor a la larga no se cristaliza en la película. Como cuando soñamos y algo nos recuerda que la realidad dista de ser así, el sueño se disipa y despertamos. Es obvio que las divisiones sociales en Venezuela son más complejas, de vieja data, Chávez no las inventó. ¿Qué ha pasado entonces?

Pueden resultar esclarecedoras unas escenas que no he abordado antes. Estamos en los primeros minutos del largometraje. Elías empieza a escribir su guión Amantes

27 Edificaciones populares. El 23 de enero es una de las más emblemáticas en Caracas, renombrada así en recuerdo de la caída de la dictadura de Marcos Pérez Jiménez. Ubicada en el oeste, ha sido una de las zonas de apoyo masivo al chavismo.

Revista Iberoamericana, Vol. LXXXI, Núm. $\quad$ L $251, \quad$ Abril-Junio $2015, \quad 601-625$
ISSN 2154-4794 (Electrónico) 
sin destino y, como si nos sumergiéramos en el mundo que está imaginando, asistimos a una escena en blanco y negro que transcurre en un casino, y donde el carácter enigmático de los personajes es acentuado por el claroscuro que los rodea. La composición caótica semeja un sueño. En el fondo del casino hay unas literas (¿un campo de concentración?) que contrastan con la mesa de la ruleta en torno a la cual se aglutinan varios personajes de diferentes rasgos étnicos, oficios y filiaciones religiosas. Excepto por un anciano que canta en húngaro y por el triángulo amoroso, nadie habla. Vicent, un militar posesivo y violento con la ingenua Nina, juega a la ruleta y decide apostar a su esposa en el juego. Quien pone a funcionar la ruleta es Federico. Vincent gana, pues la ruleta se ha detenido en 8 1/2, el número al que apostó Vincent. Sin embargo, desafiando el resultado, Federico, amante del azar, rapta a Nina, quien lo sigue, sin oponer resistencia.

El sentido de este cuadro es enigmático, como el de los sueños, y el mismo Elías desaprobará esta versión. Sin embargo, nos remite a $81 / 2$ de Fellini, un cine que se construye sobre la imposibilidad de hacer cine ajeno a toda presión, en completa libertad, y como tal, sin resolución. Otro eco intertextual conduce a Casablanca, del director Michael Curtiz (inmigrante en Estados Unidos, de origen húngaro), film en blanco y negro con rasgos expresionistas por el uso del claroscuro. Desde sus temáticas diferentes, ambas obras revelan semejanzas en la recreación personal de Schneider. Tanto el director en $81 / 2$ como los protagonistas que convergen en Casablanca son personajes vacilantes, a la deriva, huyendo de persecuciones u obligaciones, virtualmente impulsados por sus deseos en múltiples direcciones. En el café de Casablanca, convergen varias culturas, pero también el dinero y el poder: su casino es el último de varios círculos-historias convergentes. Expresión de un submundo, en el café de Rick, como en un mercado negro, se trafica con documentos ilegales y vidas, los protagonistas lo arriesgan todo por sobrevivir. La utopía de todos los recorridos posibles del deseo asoma en estas dos películas.

Varios de estos elementos hacen eco en el conflicto del casino en Des-autorizados, escena que es el punto de partida para el guión de Elías. Y si bien los personajes centrales son el triángulo Vicent-Nina-Federico, los otros personajes con su diversidad de rasgos étnicos también complementan el cuadro, pero no hablan. Después de que su productor Oscar ha vendido su obra, Elías acude insatisfecho, desmoralizado, a los ensayos teatrales (fig. 8). En una ocasión, el productor le pregunta: “¿Es imprescindible que vaya la escena del casino?, porque los números no me cuadran”. En el manuscrito original, Vicent y Nina se separan, pero ella huye con Federico. En el montaje teatral, finalmente modificada la idea del guión de Elías, Vincent y Nina quedan juntos. En cuanto a la escena del casino, de ella no volvemos a saber más.

La escena del casino alude entonces al tema de la censura. Es censurada o Elías es conminado a la autocensura y la elimina, lo que a la larga tiene el mismo efecto.

Revista Iberoamericana, Vol. LXXXI, Núm. 251, Abril-Junio 2015, 601-625 ISSN 0034-9631 (Impreso)

ISSN 2154-4794 (Electrónico) 


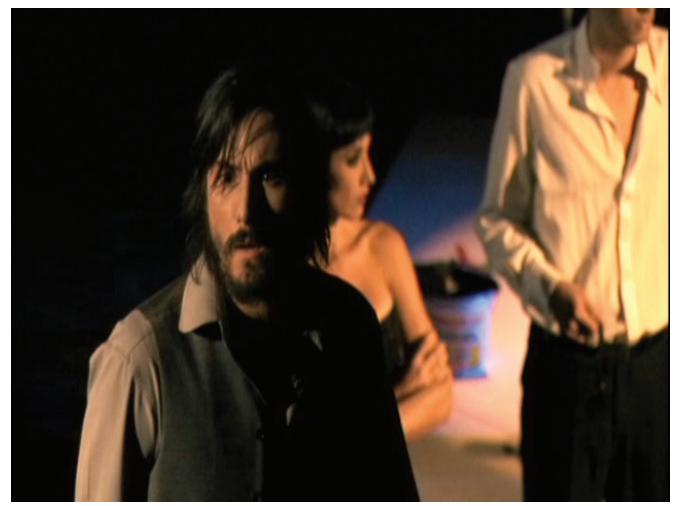

Figura 8

Pero en el guión modificado la obra sufre una deformación. Recordemos que Freud llama deformación a la aparición, en un sueño de realización de deseos, tendencias contrarias que lo llevan a encubrirse o disfrazarse, caso comparable en la vida social a la censura. Si en sus circunstancias Elías no tiene posibilidad de escribir lo que quiere, puede escribir en una forma que revele esta limitación, pero sin decirlo directamente. La retórica llama "litote" a esa figura irónica que permite negar mientras se hace una afirmación, y en Latinoamérica la conocemos como las "tretas del débil” (Ludmer).

El casino es un microcosmos multicultural pero también un espacio del imaginario onírico de Schneider (fig. 9). El anciano cantando en húngaro es una alusión a sus padres, quienes emigraron de Israel a Venezuela a finales de la década de 1950 (su madre es húngara y su padre era rumano). Es la época del primer oleaje de emigrados a Venezuela atraídos por el petróleo, sucedido por otros oleajes hasta la década de 1980, y de relativa estabilidad política y social, motivo de elección del país también para exiliados de dictaduras.

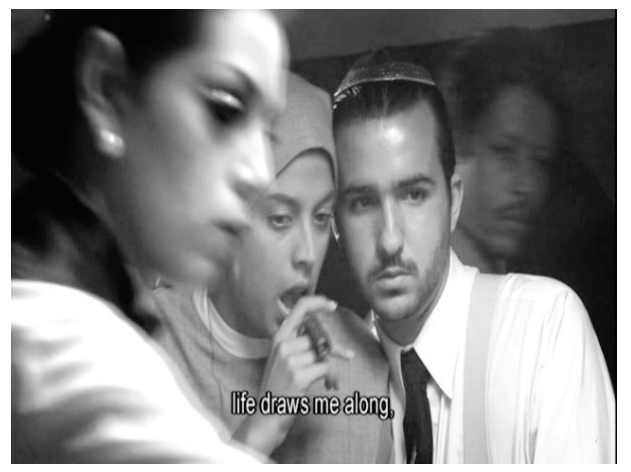

Figura 9

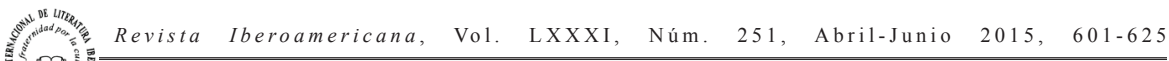


Si bien la película no hace explícito un imaginario o relato nacional (aunque el Arco de la Federación es un monumento por donde Nina y Federico deben pasar para poder recorrer la ciudad), este casino puede verse como la huella de un relato nacional fragmentado, pues la historia de la Venezuela contemporánea está inextricablemente unida al contacto intercultural con los inmigrantes (fundamental pero no exclusivamente de origen europeo y latinoamericano). Es un relato que yace reprimido en el inconsciente político, expresión de nuestras contradicciones sociales y políticas. El silencio de ese colectivo multicultural del casino así como el final de Des-autorizados recuerda que estas contradicciones no están clausuradas, aunque permanezcan silenciadas en el discurso oficial. Son un signo abierto de interrogación en torno a las polarizaciones que recorren el territorio nacional.

Una investigación futura debería ampliar la muestra de estudio, incorporando al análisis otras películas del cine venezolano del siglo XXI con similares estrategias de alusiones, alegorías y silencios, algunas de las cuales sólo he podido mencionar de paso, para poder tener una idea del alcance de esta tendencia. Y deberemos de nuevo confrontarlas con las relaciones incómodas entre cine, Estado petrolero y sociedad en Venezuela, para intentar responder las preguntas que nos hacen y entrever los desafíos de una relación diferente de la que ahora prevalece. En el polémico contrapunto social de una sociedad polarizada, hará falta también poner de relieve las diversidades políticas y culturales, así como étnicas y de género, más allá de los monólogos autoritarios de cualquier signo. La ficción no resuelve las contradicciones sociales, pero las interroga. La historia transcurre más allá de la ficción, pero estas interrogaciones son también parte de la historia.

\section{OBRAS CITADAS}

Acosta-Alzuru, Carolina. "Los medios y la telenovela a 10 años de "Cosita Rica". Prodavinci. 30 sept. 2013. <prodavinci.com/2013/09/03/actualidad/los-mediosy-la-telenovela-en-venezuela-a-los-10-años-de-costa-rica-por-carolina-acostaalzuru/>. 3 dic. 2013.

Alario, Antonieta. "El anonimato en la crítica literaria o cómo destruir al enemigo sin correr ningún riesgo". Conciencia activa 28 y 29 (2010-2011): 11-30.

Avendaño, Emily. "Hacia una nueva identidad nacional. Los cambios de nombres en la ciudad no son gratuitos". Sic 74/734 (2011): 155-158.

Barrios, Guillermo. Tramas cruzadas. El rol de la ciudad en el cine venezolano. Caracas: Universidad Central de Venezuela, 2009.

Bermúdez, Emilia. "Libertad de expresión y hegemonía en Venezuela. De la hegemonía de los medios a la hegemonía del Estado". Quórum académico 4/2 (2007): 42-60. y Natalia Sánchez. "Política, cultura, políticas culturales y consumo cultural en Venezuela”. Espacio abierto 18/3 (2009): 541-576.

\footnotetext{
Revista Iberoamericana, Vol. LXXXI, Núm. 251, Abril-Junio 2015, 601-625 ISSN 0034-9631 (Impreso) 
Bordwell, David. La narración en el cine deficción. Pilar Vázquez Mota, trad. Barcelona: Paidós, 1996.

Cilento, Alfredo. "Políticas de alojamiento en Venezuela: aciertos, errores y propuestas". Tecnología y Construcción 24/2 (2008): 35-58.

y Juan José Martín. "Para razonar un desastre. La comunicación CaracasLa Guaira, la autopista, los viaductos y la ingeniería nacional". Tecnología y Construcción 22/1 (2006): 9-27.

CNCA: Centro NacionalAutónomo de Cinematografía. "Historia". Gobierno Bolivariano de Venezuela: Ministerio del Poder Popular para la Cultura. <www.cnac.gobve/?page_id=2>. 27 nov. 2013.

CNE: Consejo Nacional Electoral. Divulgación Elecciones Presidenciales 2013. 14 abril 2013. <www.cne.gob.ve/divulgacion-presidencial-2013/index2.php?>. 3 dic. 2013. Comunidades del Relleno Sanitario del Municipio Jesús Enrique Losada del Estado Zulia. "Carta Abierta a Blanca Eckhout Presidenta Vive TV". Aporrea. 4 julio 2006. <www.aporrea.org/medios/a23247.html>. 15 dic. 2013.

Comunidades del Socuy y Maracaibo. "Carta a Blanca Ekhout Presidenta de Vive TV”. Aporrea. 30 junio 2006. <www.aporrea.org/medios/a23144.html>. 15 dic. 2013.

Coronil, Fernando. El Estado mágico. Naturaleza dinero y modernidad en Venezuela. Caracas: Nueva Sociedad, 2002.

Correia, Alexis. "La producción se triplicó gracias a la Ley del Cine". El nacional. 15 marzo 2013. <www.elnacional.com/escenas/produccion-triplico-tracias-leycine_0_154187028.html/>. 30 nov. 2013.

Des-autorizados. Elia Schneider, dir. CNAC, 2010.

Duno-Gottberg, Luis. "The Color of Mobs: Racial Politics, Etnopopulism, and Representation in the Chávez Era". Venezuela's Bolivarian Democracy. Participation, Politics and Culture Under Chávez. David Smilde y Daniel Hellinger, eds. Durham: Duke UP, 2011.

"Geografías del miedo en el cine venezolano: Soy un delincuente (1976) y Secuestro express (2005)". Ensayos. Historia y teoría del arte 19 (2010): 40-64.

"Encuentro con Elia Schneider y su nueva película Des-autorizados". Corneta. 11 marzo 2010. <www.corneta.org/no_88/elia_schneider_des_autorizados.html>. 7 junio 2015.

Farrell, Michelle Leigh. "A 'Revolution of Consciousness': Redefining Venezuelan National Identities Through Cinema". Tesis de doctorado. Georgetown University, 2011.

Filmografia venezolana (1973-1999): largometrajes. Caracas: Cinemateca Nacional de Venezuela, 2000.

Freud, Sigmund. La interpretación de los sueños. 1900. Madrid:Alianza Editorial, 1996.

Revista Iberoamericana, Vol. LXXXI, Núm. 251, Abril-Junio 2015, 601-625 
González Casas, Lorenzo y Orlando Marín. “Caracas al mar: El acceso de Caracas al Litoral y el proyecto de túnel por Altamira (1948-1958)”. Tiempo y Espacio 19/51 (2009): 13-31.

Gomel, Elana. "The Poetics of Censorship: Allegory as Form and Ideology in the Novels of Arkady and Boris Strugatsky”. Science Fiction Studies 22/1 (1995): 87-105.

Gomes, Miguel. "Modernidad y abyección en la nueva narrativa venezolana". Revista Iberoamericana LXXVI/232-233 (2010): 821-836.

Huelepega: ley de la calle. Elia Schneider, dir. Joel Films, Producciones Cinematográficas Filmart S.L., 1999.

Jameson, Fredric. The Political Unconscious: Narrative as a Socially Symbolic Act. Ithaca: Cornell UP, 1982.

Kozloff, Sarah. Invisible Storytellers: Voice-over Narration in American Fiction Film. Berkeley, Los Angeles: U of California P, 1988.

La lista. Un pueblo bajo sospecha. Ciudadanía activa. 24 mayo 2006. <http://www. youtube.com/watch? $\mathrm{v}=\mathrm{jS}$ _TLvphW8>. 15 dic. 2013.

Lefebvre, Henri. The Production of Space. 1974. Donald Nicholson-Smith, trad. Cambridge: Blackwell Publishing, 1991.

Libertador Morales, el justiciero. Efterpi Charalambidis, dir. Fundación Villa del Cine, 2009.

López Maya, Margarita y David González. El Estado descomunal. Conversaciones con Margarita López Maya. Caracas: El nacional, 2013.

"El 11A y la deriva autoritaria en Venezuela". Golpe al vacio. Reflexiones sobre los sucesos de abril de 2002. Luis Carlos Díaz y otros. Caracas: Lugar común, 2012. 13-34.

Ludmer, Josefina. "Tretas del débil". La sartén por el mango. Encuentro de escritoras latinoamericanas. Patricia Elena González y Eliana González, eds. 1984. Río Piedras: Ediciones Huracán, 1985. 47-54.

M., Sergio. “Des-autorizados: Deconstruyendo a Elia”.Panfletonegro.com. 4 abril 2010. $<$ www.planfetonegro.com/v/2010/04/04/des-autorizados-deconstruyendo-a-elia/>. 4 dic. 2010.

Mastronardi, Nancy. "Censo 2011: Venezuela tiene 28.946.101 habitantes". Correo del Orinoco. 9 ago. 2012. <www.correodelorinoco.gob.ve/tema-dia/censo-2011venezuela-tiene-28-946-101-habitantes/>. 15 dic. 2013.

Modo. "DESautorizados (2010)". Reseña. [Modo] Panfletonegro.com. 4 abril 2010. $<$ http://www.panfletonegro.com/v/2010/04/04/desautorizados-2010/>. 4 dic. 2010.

Muñoz, Boris. "La revolución de la conciencia: Construyendo una nueva hegemonía cultural en Venezuela". The Chávez Effect. ReVista: Harvard Review of Latin America. Otoño 2008. <http://dev.drclas.harvard.edu/revista/articles/view/1129>. 25 nov. 2013.

Revista Iberoamericana, Vol. LXXXI, Núm. 251, Abril-Junio 2015, 601-625 ISSN 0034-9631 (Impreso) 
"Plataforma del Cine y Medios Audiovisuales exhibirá 12 títulos de cinematografía venezolana". Correo del Orinoco. 26 sept. 2012. <www.correodelorinoco.gob. $\mathrm{ve} /$ nacionales/plataforma-cine-y-medios-audiovisuales-exhibira-12-tituloscinematografia-venezolana/> 30 nov. 2013.

"Proyecto de Reglamento Interno de Estímulo y Fomento a la Creación y la Producción Cinematográfica". CNAC: Centro Nacional Autónomo de Cinematografía. Gobierno Bolivariano de Venezuela: Ministerio del Poder Popular para la Cultura. 14 feb. 2012. $<$ http://www.cnac.gob.ve/?p=864>. 14 dic. 2013.

Quintiliano, Marco Fabio. The Instituto Oratoria of Quintilian. H. E. Butler, trad. Cambridge: Harvard UP, 1959.

Rísquez, Diego. "El compromiso histórico". Voces y cine en América Latina. El caso de Venezuela. Lima: Fondo Editorial Cultura Peruana, 2011. 163-190.

Silva García, Mario. "El odio a Chávez o la herencia del inmigrante". Aporrea. 17 julio 2003. <www.aporrea.org/actualidad/a3888.html>. 20 nov. 2013.

Schneider, Elia. Entrevista personal. 4 dic. 2013.

Entrevista personal. 15 nov. 2012.

Entrevista personal. 1 sept. 2012.

Entrevista realizada por Pablo Gamba. Encuentro con Elia Schneider y su nueva película Des-autorizados. Vértigo. Portal del cine latinoamericano y caribeño. Feb. 2010. <http://www.corneta.org/no_88/elia_schneider_des_autorizados. html>. 20 marzo 2012.

Johan M. Ramírez. Entrevista. "La Caracas de Elia Schneider". Revista Estampa. 21 junio 2009. <http://www.eluniversal.com/estampas/anteriores/210609/ caracasde>. 3 dic. 2013.

y José Ramón Novoa. "Nuevos rostros de la marginalidad en el cine venezolano". Entrevista. Voces y cine en América Latina: el caso de Venezuela. Oscar GonzálezBarreto y Pierre Silva Ernesto, eds. Lima: Fondo Editorial Cultura Peruana, 2011. 75-106.

Wright, Winthrop. Caféc con leche: Race, Class, and National Image in Venezuela. Austin: U of Texas P, 1990. 
